\title{
Pengaruh Corporate Social Responsibility dan Komisaris Independen terhadap Agresivitas Pajak
}

\author{
Yanti Nova Lita Simorangkir*, Bambang Subroto, Wuryan Andayani \\ Fakultas Ekonomi dan Bisnis, Universitas Brawijaya, Malang \\ *yantisimorangkir11@gmail.com
}

\begin{abstract}
Abstrack
This study aims to determine the effect of the corporate sosial responsibility and independent commissioners on tax aggressiveness. This study are conducted on 130 firm-years manufacturing firms listed in the Indonesian Stock Exchange during period of 2012 to 2016, selected based on purposive sampling method. Tax aggressiveness is proxy by ETR. Corporate social responsibility activities measured based on disclosures referring to Gobal Reporting Initiative (GRI) guideline. Independent commissioner is the proportion of independent commissioner in the board of commissioners. The results show that: 1) tax aggressiveness can be suppressed by the increasing activity of corporate social responsibility, 2) tax aggressiveness is not influenced by independent commissioners in the company.
\end{abstract}

Keywords: Corporate Social Responsibility, Independent Commissioner, Tax Aggressiveness.

\section{PENDAHULUAN}

Agresivitas pajak perusahaan merupakan tindakan atau upaya yang dilakukan oleh perusahaan sehingga beban pajak yang dibayarkan oleh perusahaan lebih rendah dari jumlah yang sebenarnya. Agresivitas pajak adalah perilaku perusahaan yang berusaha untuk meminimalkan penghasilan kena pajaknya dengan aktivitas perencanaan pajak dimana dilakukan sesuai dengan batasan hukum ataupun sesuai dengan celah hukum (Frank, Lynch dan Rego, 2009).

Pajak memiliki dua pandangan berbeda oleh pemerintah maupun perusahaan. Pajak sangat penting bagi pemerintah dimana sumber penerimaan negara terbesar berasal dari penerimaan pajak. Pada tahun 2016, penerimaan negara yang berasal dari pajak mencapai $82,6 \%$. Penerimaan pajak sangat diandalkan oleh pemerintah sebagai penerimaan negara dikarenakan besarnya kontribusi pajak sehingga pemerintah cenderung semakin mengurangi ketergantungan yang berasal dari sektor lain (Suprapti, 2016). Dengan semakin pentingnya peran pajak untuk penerimaan negara, sehingga reformasi perpajakan semakin gencar dilakukan oleh pemerintah dengan maksud pengoptimalan penerimaan pajak.

Sebaliknya, pajak merupakan beban yang dapat mengurangi laba bersih yang akan diperoleh perusahaan. Dengan demikian perusahaan cenderung mengharapkan beban pajak terutang yang rendah sehingga perusahaan melakukan perencanaan pajak dalam meminimalkan penghasilan kena pajaknya. Tindakan-tindakan perusahaan dalam mengurangi beban pajak terutangnya mungkin tidak seluruhnya masuk dalam kategori pelanggaran ketentuan perpajakan, namun ketika penghematan pajak tersebut 
semakin besar maka perusahaan dianggap berperilaku agresif terhadap pajak.

Tindakan agresivitas pajak di Indonesia dapat dilihat dari beberapa hal : 1) rendahnya rasio pajak; 2) rendahnya kepatuhan wajib pajak badan; 3) kasus penghindaran pajak yang dilakukan oleh PT Coca-Cola Indonesia, PT. RNI dan PT. Toyota Manufacturing Indonesia. Rasio pajak Indonesia masih tergolong rendah dan belum dapat ditingkatkan melalui penerimaan pajak. Rasio pajak di Indonesia yang rendah dibandingkan dengan negara-negara ASEAN lainnya membuktikan bahwa peran pajak belum maksimal. Rasio pajak di Indonesia tahun 2012 sebesar 11,9\%; tahun 2013 sebesar $11,9 \%$; tahun 2014 sebesar $11,4 \%$; tahun 2015 sebesar $10,7 \%$ dan tahun 2016 sebesar 10,4\% (anggaran.depkeu.go.id). Pencapaian rasio pajak Indonesia lebih rendah jika dibandingkan dengan rasio pajak yang telah dicapai negara lain di ASEAN. Beberapa negara ASEAN telah melampaui pencapaian rasio pajak Indonesia pada 2016, seperti Vietnam 13,8\%, Singapura 14,3\%, Filipina 14,4\%, Malaysia 15,5\%, dan Thailand $17 \%$ (World Bank).

Kepatuhan WP badan usaha yang rendah yaitu hanya sebesar $58 \%$ juga membuktikan bahwa tingkat agresivitas pajak di Indonesia masih tinggi (pajak.go.id). Kemudian didukung oleh beberapa kasus penghindaran pajak yang telah dilakukan oleh beberapa perusahaan di Indonesia antara lain : Pertama, Pada tahun 2014 PT. Coca-Cola Indonesia diperiksa oleh Direktorat Jenderal Pajak (DJP) dan ditemukan bahwa PT. CCI melakukan penghindaran pajak dengan melaporkan biaya fiktif dalam pelaporan pajaknya, yaitu beban iklan sebesar Rp 566,84 milyar pada tahun 2002 hingga 2006.

Kedua, PT. RNI melakukan penghindaran pajak pada thun 2014 dengan melaporkan kerugian dimana perusahaan yang rugi tidak akan membayar pajak. Selain itu, pada pelaporan pajaknya, PT. RNI melaporkan utang yang besar serta tidak wajar kemudian memanfaatkan fasilitas pajak UMKM dimana tarif $\mathrm{PPh}$ final sebesar 1\%, sementara PT. RNI merupakan perseroan terbatas. Ketiga, tindakan agresivitas pajak yang dilakukan oleh PT. Toyota Manufacturing Indonesia (TMMIN) pada tahun 2013 yang merugikan Negara sebesar Rp 500 Milyar. PT. TMMIN melaporkan penjualan lebih rendah dari jumlah yang sebenarnya, dan melaporkan pembelian bahan baku yang tidak wajar.

Tindakan agresivitas pajak dapat memberikan manfaat misalnya penghematan pajak yang cukup besar dimana kekayaan pegang saham akan meningkat serta kompensasi manajemen juga akan meningkat (Chen, Cheng dan Shevlin, 2010). Sebaliknya, tindakan agresivitas pajak jua memiliki damapak buruk terhadap perusahaan, misalnya munculnya biaya karena otoritas pajak memeriksa dan menemukan adanya kecurangan, reputasi dan citra perusahaan yang terancam rusak dan hilangnya legitimaasi perusahaan yang berasal dari masyarakat. (Sari dan Martani, 2010; Chen et al., 2010; Lanis dan Richardson, 2012).

Reputasi dan legitimasi diciptakan oleh perusahaan melalui aktivitas corporate social responsibility (Wahyudi dan Azheri, 2011:19). Dengan demikian, reputasi dan legitimasi tersebut harus mampu dijaga dan dipelihara oleh perusahaan dengan tidak melakukan tindakan-tindakan yang tidak sejalan dengan nilai, norma dan harapan masyarakat, contohnya adalah dengan melakukan tindakan agresivitas pajak (Christensen dan Murphy, 2004; Hanlon dan Slemrod, 2009; Wilson, 2009; Lanis dan Richardson, 2012; Chan, Watson dan Woodliff, 2014).

Peran komisaris independen dalam suatu perusahaan sangatlah penting. Komisaris independen melakukan pengawasan terhadap manajemen akibat dari adanya konflik agensi dalam perusahaan (Jensen dan Meckling, 1976; Khaoula dan Ali, 2012; Zemzem dan Ftouhi, 2013), selain itu komisaris independen juga harus mampu melakukan pengawasan terhadap keputusan dan tindakan yang akan mempengaruhi masyarakat secara keseluruhan (Ibrahim, Howard dan Angelidis, 2003; Rose, 2007). 
Hal ini sangat penting bagi perusahaan untuk dapat berkembang serta tidak kesulitan dalam bertahan karena reputasi dan legitimasi yang diciptakan telah dijaga atau dipelihara dengan baik. Oleh karena itu, penting bagi komisaris independen untuk mengawasi manajemen supaya tidak melakukan tindakan-tindakan yang dapat merugikan perusahaan, misalnya tindakan agresivitas pajak.

Penelitian mengenai aktivitas corporate social responsibility dan komisaris independen terhadap tindakan agresivitas pajak perusahaan diantaranya dilakukan oleh Lanis dan Richardson, 2012; Davis, Guenther, Krull dan Williams, 2016; Lanis dan Richardson, 2011; dan Khaoula dan Ali, 2012. Lanis dan Richardson (2012) dan Davis et al., (2016) melakukan penelitian terkait pengaruh aktivitas corporate social responsibility terhadap tindakan agresivitas pajak. Penelitian yang dilakukan oleh Lanis dan Richardson (2012) menunjukkan bahwa semakin tinggi aktivitas corporate social responsibility, semakin rendah tindakan agresivitas pajak perusahaan. Dimana dalam menciptakan dan menjaga legitimasinya, pajak diterapkan sebagai bagian dari aktivitas corporate social responsibility oleh perusahaan publik di Australia. Berbeda dengan penelitian yang dilakukan oleh Davis et al., (2016) yang menemukan bahwa semakin tinggi aktivitas corporate social responsibility, semakin tinggi pula tindakan agresivitas pajak perusahaan. Hal ini dikarenakan kewajiban perpajakan tidak diterapkan sebagai bentuk agenda dalam corporate social responsibility oleh perusahaan di Amerika.

Lanis dan Richardson (2011) dan Khaoula dan Ali (2012) juga melakukan penelitian, terkait bagaimana komisaris independen dapat mempengaruhi tindakan agresivitas pajak perusahaan. Penelitian yang dilakukan oleh Lanis dan Richardson (2011) menunjukkan bahwa semakin tinggi jumlah komisaris independen dalam perusahaan akan mengurangi tindakan agresivitas pajak perusahaan. Berbeda dengan penelitian yang dilakukan oleh Khaoula dan Ali (2012) yang tidak menemukan bukti terkait adanya pengaruh signifikan komisaris independen terhadap agresivitas pajak perusahaan.

Berdasarkan pemaparan tersebut, penelitian ini bertujuan untuk mengidentifikasi bagaimana tindakan agresivitas pajak pada perusahaan Bursa Efek Indonesia dipengaruhi oleh corporate social responsibility dan komisaris independen.

Hasil penelitian ini memberikan dukungan pada aplikasi teori legitimasi dan teori agensi. Hasil penelitian ini dapat dijadikan sebagai bahan referensi penelitian selenjutnya yang ingin memperdalam penelitian mengenai hubungan corporate social responsibility, komisaris indepenedn dengan perpajakan.

Hasil penelitian ini memberikan kontribusi bagi perusahaan terkait dampak yang timbul akibat dari tindakan agresivitas pajak, dimana agresivitas pajak dapat menyebabkan rusak dan hilangnya reputasi dan legitimasi perusahaan. Hasil penelitian juga dapat memberikan masukan dan wawasan bagi perusahaan mengenai tindakan-tindakan yang penting untuk dilakukan yang dapat mempengaruhi keberlangsungan bertahan perusahaan dengan mempertimbangkan masyarakat secara keseluruhan. Contohnya adalah keputusan dan tindakan perusahaan yang dapat memberikan pengaruh terhadap keberlangsungan bertahan perusahaan melalui kepeduliannya kepada masyarakat dengan melakukan tindakan-tindakan seperti taat pajak dan terlibat secara luas dalam aktivitas corporate social responsibility.

\section{Teori Legitimasi}

Legitimasi yang berasal dari masyarakat merupakan salah satu faktor penting yang dibutuhkan oleh perusahaan atau entitas organisasi untuk dapat beroperasi, bertahan bahkan mampu dalam mengembangkan perusahaan atau entitas tersebut di masa yang akan datang (Hadi, 2011:87). Menurut Suchman (1995) legitimasi merupakan asumsi atau perpsepsi dimana setiap aktivitas atau tindakan perusahaan atau entitas telah sesuai dengan 
nilai, norma, harapan, kepercayaan masyarakat sosial.

Dengan demikian, perusahaan akan mencoba membangun dan memelihara hubungan di lingkungan sosial untuk mendapatkan legitimasi yang diperlukan oleh entitas atau perusahaan dalam melakukan operasi bisnis, bertahan dan berkembang (Gray, Khouy dan Lavers, 1995).

Legitimasi dipandang sebagai suatu hal yang sangat penting dimana diharapkan, diciptakan dan diperoleh oleh entitas atau perusahaan dari masyarakat (O'donovan, 2002). Deegan, Rankin dan Tobin, (2002) menyatakan bahwa legitimasi dapat diperoleh ketika keberadaan perusahaan dan harapan masyarakat sudah sesuai serta tidak mengganggu dan juga sesuai dengan sistim nilai dan norma dalam lingkungan dan masyarakat. Legitimasi yang telah diciptakan perusahaan dapat terancam apabila terjadi ketidaksesuaian antara perusahaan dengan harapan masyarakat (Hadi, 2011:89).

\section{Teori Agensi}

Hubungan agensi terjadi saat wewenang pengambilan keputusan didelegasikan oleh pemegang saham sebagai principal kepada orang lain sebagai agent (Jensen dan Meckling, 1976). Tugas dan tanggung jawab dalam pengoptimalan laba atau keuntungan para pemegang saham diemban oleh manajemen yang selanjutnya manajemen tersebut akan diberikan kompensasi sebagai imbalan sesuai dengan kontrak yang disepakati (Suedi dan Warno, 2010).

Konflik atau permasalahan agensi cenderung rentan terjadi pada entitas atau perusahaan yang melakukan pemisahan fungsi kepemilikan dan fungsi pengelolaan (Sudana, 2011:11), seperti harapan dan kepentingan pemegang saham yang lalai diperhatikan oleh agen atau manajemen (Jensen dan Meckling, 1976). Agen kerapkali mengambil keputusan dan melakukan tindakan-tindakan yang kurang efektif, disebabkan oleh adanya perbedangan kepentingan antara pemegang saham dengan agen (Mayangsari dan Andayani, 2015).
Terjadinya konflik agensi disebabkan pemegang saham mengalami kesulitan dalam memonitor dan mengontrol keputusan serta tindakan manajemen (Harmono, 2014:3). Maka dari itu, upaya dalam mengatasi permasalah tersebut dibutuhkan pihak ketiga yang independen agar agen bertindak sesuai dengan kepentingan prinsipal atau pemegang saham (Suedi dan Warno, 2010; Lanis dan Richardson, 2011; Zemzem dan Ftouhi, 2013; Musyarrofah dan Amanah, 2017).

\section{Agresivitas Pajak}

Pajak merupakan biaya yang signifikan bagi perusahaan yang dikenakan atas penghasilan yang diperoleh perusahaan, yang akan mengurangi laba bersih yang diterima oleh perusahaan dan pemegang saham (Chen et al., 2010). Perusahaan diduga melakukan tindakan untuk mengurangi pajak terutangnya dengan meminimalisasi penghasilan kena pajak perusahaan. Tindakan perusahaan dalam mengurangi beban pajaknya merupakan upaya untuk menghindari pajak. Frank et al., (2009) menyebutkan bahwa tindakan agresivitas pajak adalah perilaku agresif dalam mengurangi laba kena pajak dengan perencanaan pajak (tax planning) berdasarkan batasan hukum maupun celah hukum. Hanlon dan Heitzman (2010) mendefenisikan agresivitas pajak dalam makna yang luas, yaitu strategi dalam meminimalisasi pajak dengan perencanaan pajak (tax planning) yang agresif yang mengarah kepada penggelapan pajak.

Manajemen selaku pembuat keputusan akan mempertimbangkan manfaat dan rugi yang akan ditimbulkan akibat dari tindakan pajak agresif. Manfaat dari tindakan agresivitas pajak yaitu: 1) keuntungan seperti besarnya penghematan pajak yang diperoleh, yang selanjutnya akan meningkatkan jumlah kas yang akan diperoleh atau diterima oleh pemegang saham; 2) manajemen memperoleh kompensisi dari pemegang saham sebagai imbalan atas penghematan pajak yang diperoleh dari perilaku agresif pajak; 3) manajemen memiliki kesempatan dalam melakukan rent extraction, tindakan dimana manajemen berperilaku opportunistik dan 
tidak memaksimalkan kepentungan pemegang saham (Chen et al., 2010).

Di sisi lain, tindakan agresivitas pajak juga menimbulkan kerugian yaitu instansi perpajakan yang menemukan adanya kecurangan yang terjadi sehingga perusahaan mendapatkan sanksi penalti (Sari dan Martani, 2010) dan terjadinya kerusakan reputsai atau citra yang baik dikarenakan adanya aduit oleh instansi perpajakan (Chen et al., 2010).

\section{Corporate Social Responsibility}

Konsep corporate social responsibility mengandung makna bahwa perusahaan bukan merupakan entitas yang beroperasi hanya demi kepentingan perusahaan itu sendiri tetapi di sisi lain, perusahaan seharusnya juga memberikan kontribusi dan harus mampu beradaptasi dengan lingkungan serta masyarakat dimana perusahaan tersebut melakukan operasi bisnisnya (Rusdianto, 2013: 7). Dengan demikian, supaya masyarakat tidak terkena dampak tidak baik dari operasi bisnis perusahaan maka sudah seharusnya perusahaan menjalankan aktivitas bisnisnya dengan lebih baik dan sesuai dengan nilai dan harapan masyarakat (Wahyudi dan Azheri, 2011:19). Dalam hal ini, dalam upaya memperoleh respon yang baik dan bentuk timbal balik dari masyarakat sekitar, maka perusahaan melakukan aktivitas corporate social responsibility.

The World Business Council for Sustainable Development (WBSCD) mendefinisikan corporate social responsibility sebagai bentuk komitmen bisnis dimana memiliki kontribusi dalam peningkatan ekonomi disertai dengan peningkatan kualitas hidup masyarakat umum. Menurut Carrol (1979) corporate social responsibility merupakan aktivitas yang sepenuhnya mencakup kinerja ekonomi, hukum, dan etis yang dimiliki perusahaan terhadap masyarakat. Caroll (1979) menyebutkan perusahaan dengan corporate social responsibility yang baik, selain harus mampu memperoleh laba maka perusahaan tersebut juga harus patuh terhadap hukum, melakukan tindakan-tindakan etis dan menjadi warga negara yang baik melalui mendukung aktivitas-aktivitas sosial secara finansial.

Selaras dengan pandangan bisnis yang dikenal sebagai triple bottom lines, dimana dunia bisnis dituntut untuk mampu menyelaraskan pencapaian kinerja ekonomi (profit) dengan kinerja sosial (people) dan kinerja lingkungan (planet) (Rusdianto, 2013:8). Untuk mampu melakukan interaksi dengan masyarakat, maka perusahaan melakukan pengungkapan corporate social responsibility sebagai sarana dalam mempengaruhi persepsi (Hooghiemstra, 2000; Tan et al., 2016). Melalui pengungkapannya, ditemukan sejauh mana aktivitas corporate social responsibility perusahaan yang telah dilakukan. Di Indonesia, sejauh ini belum terdapat standar khusus yang mengatur tentang pengungkapan corporate social responsibility. Acuan yang digunakan untuk menyusun pengungkapan corporate social responsibility adalah Global Reporting Initiative (GRI) (Gustian dan Faisal, 2015).

\section{Komisaris Independen}

Dewan komisaris merupakan bagian perusahaan yang memiliki tujuan sebagai pengawas serta memiliki tugas dan wewenang yang bertanggung jawab sekaligus memberikan nasihat kepada direksi. Dewan komisaris bertanggung jawab secara kolektif dalam menjalankan tugasnya untuk mengawasi serta memberikan nasihat dan memastikan secara pasti bahwa perusahaan telah melaksanakan corporate governance dengan baik dan benar (KNKG, 2006). Komisaris independen merupakan bagian dari dewan komisaris, dimana berdasarkan Undang-Undang Republik Indonesia Nomor 40 Tahun 2007 Tentang Perseroan Terbatas, komisaris independen merupakan anggota dewan komisaris yang diangkat berdasarkan keputusan RUPS (Rapat Umum Pemegang Saham) dari pihak yang tidak memiliki afiliasi dengan pemegang saham utama, anggota direksi dan atau anggota dewan komisaris lainnya. 
Fama dan Jensen (1983) menyebutkan bahwa dewan komisaris merupakan perangkat tata kelola perusahaan yang signifikan dalam mengawasi atau memantau keputusan perusahaan dan untuk mempekerjakan, memberhentikan dan memberi kompensasi kepada manajer yang ada di dalam perusahaan. Dewan komisaris dalam perusahaan tidak hanya bertanggung jawab dalam mengawasi perilaku manajemen terhadap pemegang saham saja, tetapi juga harus memperhatikan dan mempertimbangkan kepentingan atau kebutuhan masyarakat secara keseluruhan. Dengan demikian dewan komisaris harus mengawasi manajemen untuk memastikan bahwa harapan pemangku kepentingan dan masyarakat dapat diatasi dan dipenuhi (Lanis dan Richardson, 2011).

\section{Pengaruh Corporate Social Responsibility terhadap Agresivitas Pajak Perusahaan \\ Corporate social responsibility adalah} suatu upaya yang dilakukan sebagai bentuk kepedulian perusahaan terhadap masyarakat dan lingkungan sekitar yang menjadi strategi perusahaan untuk menciptakan legitimasi dan reputasi perusahaan sehingga dapat diterima oleh masyarakat. Sejalan dengan pandangan Avi-Yonah (2006) yang menyatakan perusahaan menerapkan aktivitas corporate social responsibility tidak hanya demi memaksimalkan keuntungan pemegang saham, tetapi juga lebih luas harus mempertimbangkan pemangku kepentingan lainnya seperti kelompok politik, karyawan, pemerintah dan masyarakat (Ghozali dan Chariri, 2007:409). Lanis dan Richardson (2012) menyebutkan perusahaan dalam pengambilan keputusan operasi bisnisnya, dapat menggunakan prinsip-prinsip yang terkandung dalam corporate social responsibility sebagai pedoman dalam tindakan dan keputusan etis perusahaan dengan mempertimbangkan pemegang saham sekaligus masyarakat.

Perusahaan sebagai entitas real world (Avi-Yonah, 2006) yaitu membayar pajak merupakan kewajiban sosial perusahaan. Pajak yang disetor oleh perusahaan sangat bermanfaat untuk masyarakat dimana melalui pajak maka akan membantu dalam pendanaan penyediaan barang publik dalam masyarakat (Laguir, Stagliano dan Elbaz, 2015), misalnya kesehatan, pendidikan, penegakan hukum serta tranportasi umum. Sehingga, perilaku agresif pajak merupakan perilaku yang akan memberikan dampak tidak baik terhadap masyarakat.

Selaras dengan pandangan teori legitimasi, yang menyatakan bahwa perusahaan harus menciptakan dan memelihara hubungan di lingkungan sosial untuk mendapatkan legitimasi yang dibutuhkan perusahaan sehingga mampu melakukan operasi bisnis, bertahan bahkan berkembang (Gray et al., 1995). Untuk mampu menjaga dan memelihara legitimasi yang telah diciptakan melalui aktivitas corporate social responsibility, maka perusahaan harus berhati-hati dalam melakukan tindakan-tindakan lain yang berbeda dengan nilai, norma dan harapan masyarakat serta otoritas pajak (Christensen dan Murphy, 2004). Perusahaan seharusnya tidak melakukan tindakan agresivitas pajak yang akan menyebabkan rusaknya reputasi perusahaan dan hilangnya legitimasi perusahaan yang akan mengancam keberlangsungan operasi bisnis perusahaan (Hanlon dan Slemrod, 2009; Wilson, 2009; Chan et al., 2014).

H1: Tanggung jawab sosial perusahaan berpengaruh negatif terhadap agresivitas pajak perusahaan.

\section{Pengaruh Komisaris Independen terhadap Agresivitas Pajak Perusahaan}

Tindakan-tindakan manajemen sangatlah sulit untuk dimonitor dan dikontrol oleh pemegang saham (Harmono, 2014:3). Tindakan agresivitas pajak merupakan suatu upaya yang dilakukan manajemen untuk kepentingannya sendiri dengan harapan akan memperoleh bonus dari pemegang saham, dengan memanfaatkan kekayaan penegang saham (Lanis dan Richardshon, 2011; Suyanto dan Supramono, 2012). Kehadiran komisaris independen dalam dewan komisaris mampu meningkatkan pengawasan kinerja direksi dan manajemen (Fama dan Jensen, 
1983; Khaoula dan Ali, 2012; Zemzem dan Ftouhi, 2013).

Teori legitimasi menekankan pentingnya peran komisaris independen dalam mengawasi perilaku dan sikap manajemen dalam pengambilan keputusan serta dalam melakukan tindakan-tindakannya. Dengan harapan bahwa setiap keputusan dan tindakan tersebut tetap mampu memelihara serta mempertahankan legitimasi perusahaan (Lanis dan Richardson, 2011). Ibrahim et al., (2003) dan Rose (2007) menyatakan sangat penting bagi komisaris independen untuk dapat memantau perilaku atau sikap dan keputusan perusahaan dengan memperhatikan dan mempertimbangkan kebutuhan masyarakat secara keseluruhan dan mematuhi peraturan-peraturan yang berlaku dimana perusahaan tersebut melakukan operasi bisnisnya. Dengan demikian, komisaris independen harus mampu memonitor atau memantau sikap, perilaku, keputusan dan tindakan manajemen sehingga tidak akan melakukan tindakan dimana legitimasi perusahaan dapat terancam seperti tidak melakukan tindakan agresivitas pajak (Armstrong, Blouin, Jagolinzer dan Larcker, 2015).

$\mathrm{H} 2$ : Proporsi komisaris independen berpengaruh negatif terhadap agresivitas pajak perusahaan.

\section{METODE}

Sampel penelitian ini dipilih menggunakan purposive sampling dengan kriteria: 1) Perusahaan manufaktur yang terdaftar di Bursa Efek Indonesia mulai tahun 2012 hingga 2016; 2) Data penelitian yang dibutuhkan lengkap, yaitu laporan tahunan dan laporan keuangan; 3) Perusahaan menggunakan satuan nilai rupiah dalam laporan keuangannya; 4) ETR kurang dari 1; 5) Perusahaan tidak mengalami kerugian.

Berdasarkan seleksi sampel yang dilakukan berdasarkan kriteria-kriteria yang ditetapkan sebelumnya maka diperoleh sampel sebesar 48 sampel perusahaan. kemudian ketika dilakukan screening pada data ditemukan adanya outlier pada 22 data, sehingga data yang digunakan adalah sebesar
26 sampel data. Dengan demikian, jumlah observasi pada penelitian ini yaitu sebanyak 130 sampel tahun perusahaan.

Tabel 1. Sampel Penelitian

\begin{tabular}{lr}
\hline $\begin{array}{l}\text { Perusahaan manufaktur tercatat } \\
\text { di BEI pada tahun 2012-2016 }\end{array}$ & $\mathbf{1 4 4}$ \\
Tidak konsisten listing/delisting & $(17)$ \\
$\begin{array}{l}\text { Data penelitian yang tidak lengkap } \\
\text { Laporan keuangan menggunakan } \\
\text { mata uang dolar }\end{array}$ & $(26)$ \\
$\begin{array}{l}\text { ETR }>1 \\
\begin{array}{l}\text { Perusahaan rugi } \\
\text { Sampel perusahaan berdasarkan } \\
\text { purposive sampling }\end{array}\end{array}$ \\
$\begin{array}{l}\text { Data } \text { outlier } \\
\text { Sampel perusahaan setelah } \\
\text { screening data }\end{array}$ \\
$\begin{array}{l}\text { Total sampel tahun perusahaan } \\
\text { (26 perusahaan } x \text { 5 tahun) }\end{array}$ \\
$\begin{array}{l}\text { Sumber: Data diolah, 2018 } \\
\text { (26) }\end{array}$ \\
\end{tabular}

\section{Agresivitas pajak}

Agresivitas pajak diukur dengan Effective Tax Rate (ETR). Effective Tax Rate (ETR) menggambarkan persentase total beban pajak yang dibayarkan oleh perusahaan dibandingkan total laba sebelum pajak yang diperoleh perusahaan (Lanis dan Richardson 2012

$$
E T R=\frac{\text { Beban Pajak }}{\text { Laba Sebelum Pajak }}
$$

\section{Corporate Social Responsibility}

Tingkat aktivitas corporate social responsibility diukur dengan menggunakan proksi indeks pengungkapan corporate social responsibility (Lanis dan Richardson, 2012). Butir-butir pengungkapan corporate social responsibility yang digunakan adalah berdasarkan pedoman berkelanjutan GRI yang terdiri dari 79 aspek pengungkapan. Kemudian dilakukan pencocokan item berdasarkan check list dengan item pengungkapan pada laporan tahunan perusahaan. 
Berikut ini rumus yang digunakan dalam menghitung CSRI :

$$
\mathrm{CSRIj}=\frac{\sum \mathrm{Xij}}{\mathrm{nj}}
$$

CSRIj : indeks luas pengungkapan corporate social responsibility $\mathrm{j}$

$\sum \mathrm{Xi} \quad$ : nilai 1 jika item i diungkapkan; nilai 0 jika item i tidak diungkapkan

$\mathrm{Nj} \quad$ : jumlah item untuk perusahaan $\mathrm{j}, \mathrm{nj} \leq$ 79

\section{Komisaris Independen}

Komisaris independen diukur berdasarkan jumlah komisaris independen dibandingkan total dewan komisarisvdalam perusahaan (Lanis dan Richardson, 2011; Khaoula dan Ali, 2012), yaitu:

$$
\mathrm{KI}=\frac{\text { Jumlah Komisaris Independen }}{\text { Jumlah Dewan Komisaris }}
$$

\section{Variabel Kontrol}

Kepemilikan manajerial (MTOBD) merupakan kepemilikan saham oleh manajemen perusahaan yang terdiri dari direksi dan manajer. Tindakan-tindakan yang dilakukan manajemen kerapkali berbeda dengan harapan dan kepentingan pemegang saham (Hu dan Izumida, 2008). Sehingga, perusahaan membuat kebijakan dengan memberlakukan kepemilikan saham bagi pihak manajemen, dengan harapan manajemen akan senantiasa berhati-hati ketika mengambil keputusan dan melakukan suatu tindakan (Jensen dan Meckling, 1976; $\mathrm{Hu}$ dan Izumida, 2008). MTOBD diukur berdasarkan jumlah saham yang dimiliki oleh manajemen dibagi dengan proporsi saham yang beredar.

Leverage (LEV) adalah kemampuan perusahaan dalam melakukan pembayaran utang-utangnya, baik utang pokok maupun bunganya (Hadi dan Mangoting, 2014). Beban bunga merupakan beban yang timbul dari adanya utang, dimana beban tersebut dapat dimanfaatkan sebagai pengurang pajak, sehingga semakin tinggi leverage maka tindakan agresivitas pajak juga akan semakin tinggi (Suyanto dan Supramono, 2012). Pengukuran leverage adalah berdasarkan total utang dibagi dengan total aset perusahaan.

Intensitas modal (CINT) menunjukkan seberapa besar modal yang diperlukan untuk menghasilkan laba. Adanya penyusutan aset tetap perusahaan setiap tahunnya akan menjadi biaya yang dapat menjadi pengurang pajak, sehingga semakin tinggi intensitas modal perusahaan maka tindakan agresivitas pajak perusahaan juga semakin tinggi (Siregar dan Widyawati, 2016). Pengukuran intensitas modal adalah berdasarkan jumlah aset tetap yang dimiliki oleh perusahaan dibagi dengan total aset perusahaan.

ROA (Return on Asset) adalah salah satu pengukuran profitabilitas perusahaan. Besarnya laba yang diperoleh perusahaan, akan meningkatkan beban pajak yang dibayar oleh perusahaan. Sehingga perusahaan akan cenderung berusaha untuk meminimalkan pajak terutangnya (Puspita dan Febrianti, 2017). Lanis dan Richardson (2012) menemukan bahwa ROA berpengaruh positif terhadap agresivitas pajak perusahaan. ROA diukur dengan pendapatan sebelum pajak dibandingkan dengan total aset.

\section{Teknik Analisis Data}

Teknik analisis data dalam penelitian ini meliputi statistik deskriptif, uji asumsi klasik (terdiri dari normalitas, multikolineritas, heterokedastisitas dan autokorelasi) dan uji hipotesis yaitu dengan uji t atau uji parsial. Pengujian pada penelitian ini dilakukan dengan bantuan aplikasi SPSS 23.

\section{HASIL DAN PEMBAHASAN \\ Hasil Effective Tax Rate (ETR)}

Pengujian terhadap 130 sampel amatan, menunjukkan bahwa Effective Tax Rate (ETR) memiliki nilai rata-rata sebesar 0,246 atau 24,6\%. Dilihat dari nilai ETR sebesar $24,6 \%$ menunjukkan pajak terutang perusahaan sampel berada dibawah tarif pajak yang berlaku yaitu sebesar 25\%. Nilai minimum ETR berdasarkan 130 sampel, menunjukkan nilai sebesar 0,155 atau 15,5\%. Nilai maksimum ETR berdasarkan 130 
sampel amatan menunjukkan nilai sebesar 0,368 atau 36,8\%. Standar deviasi ETR berdasarkan 130 sampel amatan menunjukkan nilai sebesar 0,033 atau 3,3\%. Nilai standar deviasi lebih rendah dibandingkan nilai rata-rata, yaitu 0,033 < 0,246 menunjukkan bahwa penyimpangan data dan keberagaman nilai ETR dari perusahaan sampel relatif kecil.

Tabel 2. Statistik Deskriptif

\begin{tabular}{lccccc}
\hline Variabel & $\mathrm{N}$ & Minimum Maximum & Mean & $\begin{array}{c}\text { Std. } \\
\text { Deviation }\end{array}$ \\
\hline $\begin{array}{l}\text { Agresivi } \\
\text { tas Pajak }\end{array}$ & 130 & 0,155 & 0,368 & 0,246 & 0,033 \\
CSR & 130 & 0,063 & 0,456 & 0,173 & 0,078 \\
KI & 130 & 0,25 & 0,8 & 0,397 & 0,114 \\
MTOBD & 130 & 0 & 0,261 & 0,028 & 0,063 \\
LEV & 130 & 0,111 & 0,752 & 0,402 & 0,167 \\
CINT & 130 & 0,04 & 0,784 & 0,31 & 0,162 \\
ROA & 130 & 0,013 & 0,885 & 0,188 & 0,148 \\
\hline
\end{tabular}

Sumber: Data sekunder yang diolah, 2018

Pada tabel 2 dapat dilihat pengujian terhadap 130 sampel, menunjukkan bahwa aktivitas corporate social responsibility (CSR) memiliki nilai rata-rata sebesar 0,173 atau $17,3 \%$. Dengan demikian corporate social responsibility perusahaan sampel masih tergolong rendah. Nilai minimum corporate social responsibility berdasarkan 130 sampel amatan menunjukkan nilai sebesar 0,063 atau 6,3\%. Nilai maksimum corporate social responsibility berdasarkan 130 sampel amatan menunjukkan nilai sebesar 0,456 atau $45,6 \%$. Dan standar deviasi corporate social responsibility berdasarkan 130 sampel amatan menunjukkan nilai sebesar 0,078 atau $7,8 \%$. Nilai standar deviasi lebih rendah dibandingkan nilai ratarata, yaitu 0,078<0,173 menunjukkan bahwa penyimpangan data dan keberagaman nilai corporate social responsibility dari perusahaan sampel relatif kecil.

Pengujian terhadap 130 sampel amatan, menunjukkan bahwa komisais independen (KI) memiliki nilai rata-rata sebesar 0,397 atau $39,7 \%$. Nilai minimum komisais independen berdasarkan 130 sampel amatan menunjukkan nilai sebesar 0,25 atau $25 \%$.
Nilai maksimum komisais independen berdasarkan 130 sampel amatan menunjukkan nilai sebesar 0,8 atau $80 \%$. Standar deviasi komisais independen berdasarkan 130 sampel amatan menunjukkan nilai sebesar 0,114 atau $11,4 \%$. Nilai standar deviasi lebih rendah dibandingkan nilai rata-rata, yaitu $0,114<$ 0,397 menunjukkan bahwa penyimpangan data dan keberagaman nilai komisais independen dari perusahaan sampel relatif kecil.

\section{Uji Normalitas}

Tabel 3. Hasil Uji Normalitas

\begin{tabular}{lc}
\hline & $\begin{array}{c}\text { Unstandardized } \\
\text { Predicted Value }\end{array}$ \\
\hline K-Smirnov Z & 0,055 \\
Signifikansi & 0,200 \\
\hline Sumber: Data sekunder yang diolah, 2018
\end{tabular}

Hasil pengujian asumsi normalitas pada tabel 3 menunjukkan residual berdistribusi normal. Dengan demikian asumsi normalitas terpenuhi.

\section{Uji Multikolineritas}

Tabel 4. Hasil Uji Multikolineritas

\begin{tabular}{lcc}
\hline Variabel Independen & \multicolumn{2}{c}{$\begin{array}{c}\text { Collinearity } \\
\text { Statistics }\end{array}$} \\
\cline { 2 - 3 } & Tolerance & VIF \\
\hline CSR & 0,864 & 1,158 \\
KI & 0,710 & 1,409 \\
MTOBD & 0,811 & 1,233 \\
LEV & 0,613 & 1,632 \\
CINT & 0,562 & 1,779 \\
ROA & 0,777 & 1,287 \\
\hline
\end{tabular}

Sumber: Data sekunder yang diolah, 2018

Berdasarkan hasil pengujian multikolineritas pada tabel 4, maka dapat disimpulkan bahwa seluruh variabel independen menghasilkan nilai VIF yang lebih rendah dari 10 dan nilai tolerance lebih tinggi dari 0,1. Sehingga tidak terjadi masalah multikolineritas antar variabel independen. 


\section{Uji Heterokedastisitas}

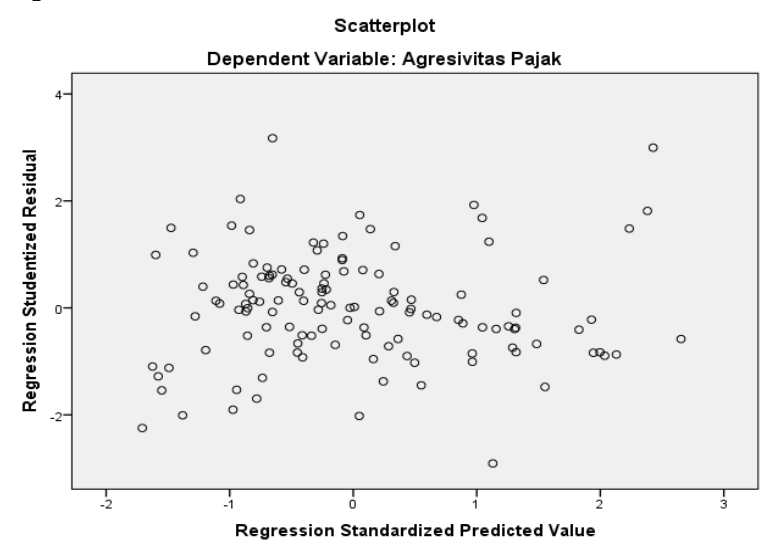

Gambar 1. Hasil Uji Heterokedastisitas

Sumber: Data sekunder yang diolah, 2018

Berdasarkan scatter plot pada gambar 1 dapat diketahui bahwa titik-titik residual menyebar secara acak, sehingga asumsi heteroskedastisitas dinyatakan terpenuhi.

\section{Uji Autokorelasi}

Tabel 5. Hasil Uji Autokorelasi

\begin{tabular}{lc}
\hline $\mathrm{Z}$ & 2,113 \\
\hline Signifikansi & 0,35 \\
\hline
\end{tabular}

Sumber: Data sekunder yang diolah, 2018

Hasil pengujian pada tabel 5 menunjukkan bahwa nilai signifikansi lebih besar dari 0,05, sehingga tidak terjadi masalah autokorelasi

\section{Pembahasan}

Berdasarkan hasil output SPSS 23, diketahui adj $\mathrm{R}^{2}$ sebesar 0,184. Artinya, kontribusi Corporate Social Responsibility (CSR), Komisaris Independen (KI), Kepemilikan Manajerial (MTOBD), Leverage (LEV), Intensitas Modal (CINT) dan Return On Asset (ROA) terhadap Agresivitas Pajak (ETR) adalah sebesar $18,4 \%$, sedangkan sisanya sebesar $81,6 \%$ merupakan kontribusi dari variabel lain yang tidak dibahas dalam penelitian ini.
Tabel 6. Hasil Uji Hipotesis

\begin{tabular}{lccc}
\hline \multicolumn{1}{c}{ Variabel } & $\begin{array}{c}\mathrm{t}- \\
\text { Statistic }\end{array}$ & Sig & $\begin{array}{c}\text { Kesimpu } \\
\text { lan }\end{array}$ \\
\hline $\begin{array}{l}\text { Corporate Social } \\
\text { Responsibility }\end{array}$ & & & \\
$\begin{array}{l}\text { (CSR) } \\
\text { Komisaris }\end{array}$ & $-2,932$ & 0.004 & Diterima \\
$\begin{array}{l}\text { Independen (KI) } \\
\text { Variabel Kontrol : }\end{array}$ & $-0,213$ & 0.831 & Ditolak \\
$\quad$ Kepemilikan & & & \\
$\quad$ Manajerial & & & \\
$\quad$ MTOBD) & 1,532 & 0.128 & \\
$\quad \begin{array}{l}\text { Leverage (Lev) } \\
\text { Intensitas }\end{array}$ & 0,206 & 0.837 & \\
$\quad$ Modal (CINT) & 3,464 & 0.001 & \\
$\quad$ ROA & 0,403 & 0.688 & \\
\hline
\end{tabular}

*) tingkat signifikansi pada $\alpha=5 \%$

Sumber : data diolah

\section{Pengaruh Corporate Social Responsibility terhadap Agresivitas Pajak}

Berdasarkan hasil uji t pada tabel 6, aktivitas corporate social responsibility diperoleh nilai signifikansi sebesar 0,004 yang menunjukkan nilai signifikansi < level of significance $(\alpha=5 \%)$. Dengan demikian hipotesis pertama (H1) diterima yaitu bahwa aktivitas corporate social responsibility berpengaruh negatif terhadap tindakan agresivitas pajak perusahaan. Hal ini berarti semakin tinggi tingkat aktivitas corporate social responsibility, maka akan semakin rendah tindakan agresivitas pajak perusahaan.

Hasil penelitian ini berbeda dengan penelitian terdahulu yang dilakukan oleh Lanis dan Richardson (2012). Dalam penelitiannya, Lanis dan Richardson (2012) menyebutkan tindakan agresivitas pajak perusahaan dapat ditekan dengan semakin tingginya aktivitas corporate social responsibility. Lebih lanjut dikatakan bahwa pembayaran pajak diterapkan oleh perusahaan Australia sebagai bentuk dari aktivitas corporate social responsibility sebagai upaya untuk menciptakan dan memelihara citra yang baik dan legitimasi dari masyarakat.

Hasil penelitian ini berbeda dengan penelitian yang dilakukan oleh Davis et al., (2016) yang menunjukkan bahwa perusahaan publik di Amerika yang bertanggungjawab 
secara sosial cenderung melakukan tindakan agresivitas pajak. Dimana pembayaran pajak tidak diterapkan oleh perusahaan Amerika sebagai agenda dari aktivitas corporate social responsibility.

Hasil penelitian ini sesuai dengan pandangan teori legitimasi dalam perpajakan yang menyebutkan bahwa terdapat relasi antara perusahaan dan masyarakat untuk melakukan tindakan-tindakan dan berperilaku yang sesuai dengan harapan, nilai serta norma dalam masyarakat. Dengan demikian legitimasi dan reputasi yang baik dapat diciptakan dan dipelihara oleh perusahaan. Legitimasi dan citra yang baik adalah faktor penting yang sangat dibutuhkan oleh perusahaan untuk dapat melakukan operasi bisninya, bertahan dan selalu berkembang.

Selain memperhitungkan ekonomi aktivitas corporate social responsibility juga merupakan tindakan yang memperhatikan dan mempertimbangkan sosialnya. Dengan taat terhadap peraturan yang berlaku, termasuk peraturan perpajakan dan melakukan pembayaran pajak sesuai dengan aturan perpajakan yang berlaku merupakan salah satu bentuk tanggung jawab perusahaan terhadap masyarakat.

\section{Pengaruh Komisaris Independen terhadap Agresivitas Pajak}

Berdasarkan hasil uji t pada tabel 6, Komisaris Independen (KI) diperoleh nilai signifikansi sebesar 0,831 yang menunjukkan nilai signifikansi > level of significance $(\alpha=5 \%)$. Dengan demikian hipotesis kedua (H2) yang menyebutkan bahwa komisaris independen berpengaruh negatif terhadap agresivitas pajak ditolak. Hasil penelitian membuktikan bahwa tindakan agresivitas pajak perusahaan tidak dipengaruhi oleh komisaris independen,

Hasil penelitian ini berbeda dengan hasil penelitian yang dilakukan oleh Lanis dan Richardson (2011) yang menemukan bahwa tindakan agresivitas pajak perusahaan dapat berkurang dengan semakin tingginya proporsi komisaris independen dalam perusahaan publik di Australia. Hasil penelitian ini sesuai dengan penelitian yang dilakukan oleh Khaoula dan Ali (2012) yang melakukan penelitian pada perusahaan publik di Tunisia dan tidak menemukan bukti adanya pengaruh dari komisaris independen terhadap agresivitas pajak perusahaan.

Berdasarkan hasil penelitian yang menemukan tidak berpengaruhnya komisaris independen terhadap agresivitas pajak, menunjukkan bahwa upaya pencegahan tindakan agresivitas pajak masih belum efektif dilakukan oleh komisaris independen dalam suatu perusahaan (Khoula dan Ali, 2012). Keberadaan komisaris independen dalam perusahaan juga tidak mampu dalam melaksanakn fungsi monitoring dengan baik pada manajemen dalam pengambilan keputusan dan tindakan strategis seperti tindakan agresivitas pajak yang mempunyai dampak tidak baik bagi perusahaan seperti merusak reputasi dan menghilangkan legitimasi perusahaan. Hasil penelitian juga berbeda dengan pandangan Ibrahim et al., (2003) dan Rose (2007) yang menyatakan bahwa kehadiran komisaris independen sangat penting untuk dapat mengawasi keputusan dan tindakan manajemen dengan mempertimbangkan kebutuhan masyarakat. Oeleh karena itu, disimpulkan bahwa hasil penelitian tidak dapat mendukung teori legitimasi seperti pada penelitian yang dilakukan oleh Lanis dan Richardson (2011).

Dengan rata-rata jumlah komisaris independen sebesar $38,7 \%$ menunjukkan bahwa jumlah tersebut tidak signifikan dalam mengawasi perilaku manajemen untuk dapat patuh dan taat pajak sesuai dengan peraturan perpajakan yang sedang berlaku dengan menekan tindakan agresivitas pajak. Dengan demikian kehadiran komisaris independen dalam perusahaan hanya merupakan kebutuhan terhadap kepatuhan peraturan. Seperti pada Peraturan Otoritas Jasa Keuangan No. 33/POJK.04/2014 tentang Direksi dan Dewan Komisaris Emiten atau Perusahaan Publik yang menyatakan bahwa perusahaan publik harus memiliki komisaris independen minimal sebesar $30 \%$ dari total dewan komisaris. 


\section{Variabel Kontrol}

Kepemilikan manajerial (MTOBD) tidak terbukti dapat mengurangi tindakan agresivitas pajak. Hasil penelitian ini berbeda dengan hasil penelitian Musyarrovah dan Amanah (2017) yang menemukan bahwa tindakan agresivitas pajak dapat dikurangi melalui kepemilikan saham oleh manajemen. Tidak adanya pengaruh kepemilikan manajerial terhadap agresivitas pajak dapat disebabkan rendahnya saham yang dimiliki oleh manajemen perusahaan publik di Indonesia (Novitasari et al., 2017). Berdasarkan hasil penelitian ditemukan bahwa rata-rata kepemilikan manajerial hanya sebesar 0,028 . Jumlah tersebut sangat kecil yaitu dibawah 5\% dibandingkan dengan jumlah kepemilikan investor lain sehingga tidak dapat dapat mempengaruhi keputusan dan tindakan dalam manajemen termasuk tindakan agresivitas pajak.

Leverage (LEV) tidak terbukti dapat meningkatkan tindakan agresivitas pajak perusahaan. Hal ini berbeda dengan penelitian yang dilakukan oleh Suyanto dan Supramo (2012) yang menyebutkan bahwa utang menimbulkan bunga yang dapat mengurangi pajak. Kurniasih dan Sari (2013) menyatakan bahwa tingginya leverage mengindikasikan tingginya jumlah pembiayaan perusahaan dari pihak ketiga yang mengakibatkan biaya bunga yang tinggi pula. Sehingga perusahaan akan tidak melakukan pendanaan melalui hutang dengan bunga yang besar hanya untuk sekedar menghindari pajaknya.

Intensitas modal (CINT) berpengaruh positif terhadap tindakan agresivitas pajak. Hasil penelitian ini sama hasil penelitian Lanis dan Richardson (2012) yang menyatakan bahwa tindakan agresivitas pajak perusahaan akan meningkat dengan semakin tingginya intensitas modal perusahaan. Hal ini dikarenakan beban pajak akan berkurang dengan adanya penyusutan aset tetap setiap tahunnya, dimana penyusutan tersebut merupakan biaya yang dapat menjadi pengurang pajak perusahaan.

ROA tidak terbukti dapat meningkatkan agresivitas pajak perusahaan. Hasil penelitian ini berbeda dengan penelitian yang dilakukan oleh Lanis dan Richarsdon (2012) yang menemukan bahwa perusahaan dengan tingkat ROA yang tinggi cenderung berperilaku agresif terhadap pajak. Hasil penelitian juga berbeda dengan pernyataan Puspita dan Febrianti, (2017) yang menyebutkan bahwa besarnya laba perusahaan, akan menjadi faktor untuk perusahaan dalam meminimalkan pajak terutangnya mengingat semakin tingginya laba, maka beban pajak perusahaan juga akan semakin tinggi. Dalam penelitiannya, Rosalia dan Sapari (2017) menemukan bahwa ROA tidah berpengaruh terhadap tindakan penghindaran pajak. Dalam penelitian tersebut disebutkan bahwa tindakan agresivitas pajak memiliki risiko cukup besar, sehingga tinggi rendahnya ROA maka tidak akan memiliki pengaruh terhadap perilaku agresif pajak perusahaan.

\section{Kesimpulan}

Hasil penelitian membuktikan bahwa agresivitas pajak dipengaruhi oleh corporate social responsibility. Agresivitas pajak perusahaan dipengaruhi secara negatif oleh corporate social responsibility. Artinya tindakan agresivitas pajak perusahaan dapat ditekan atau berkurang dengan semakin tingginya aktivitas corporate social responsibility. Dimana perusahaan manufaktur Indonesia lebih berhati-hati dalam melakukan tindakan-tindakan, misalnya tindakan agresivitas pajak yang dapat merusak citra baik dan menghilangkan legitimasi perusahaan yang telah diciptakan melalui aktivitas corporate social responsibility.

Hasil penelitian menunjukkan bahwa agresivitas pajak tidak dipengaruhi oleh komisaris independen. Hal ini berarti kehadiran komisaris independen dalam perusahaan tidak efektif dalam melakukan pengawasan terhadap keputusan dan tindakan manajemen, misalnya dalam mengawasi tindakan agresivitas pajak.

Pengujian terhadap variabel kontrol menunjukkan bahwa agresivitas pajak dipengaruhi oleh intensitas modal. Agresivitas pajak dipengaruhi secara positif 
oleh intensitas modal, artinya perilaku agresif pajak akan semakin mengingkat, dengan semakin tingginya intensitas modal perusahaan. Hal ini dikarenakan pajak terhutang perusahaan akan berkurang dengan adanya penyusutan aset tetap perusahaan setiap tahunnya. Agresivitas pajak tidak dipengaruhi oleh kepemilikan manajerial, leverage dan Return On Assets (ROA).

\section{DAFTAR PUSTAKA}

Anggaran Pendapatan dan Belanja Daerah. 2017. Diakses 13 Januari 2018, dari http://www.anggaran.depkeu.go.id/conte nt/publikasi/BIBAPBNP2017.pdf

Armstrong, C. S., Blouin, J. L., Jagolinzer, A. D., dan Larcker, D. F. 2015. Corporate Governance, Incentives, and Tax Avoidance. Journal of Accounting and Economics 60:1-17.

Avi-Yonah, Reuven S. 2006. Corporate Social Responsibility And Strategic Tax Behaviour. Public Law And Legal Theory Working Paper Series. Working Paper No. 69

Carrol, A. B. 1979. A Three-Dimensional Conceptual Model of Corporate Performance. Academy of Management Review 4(4): 497-505.

Chan, M. C., Watson, J., dan Woodliff, D. 2014. Corporate Governance Quality and CSR Disclosures. Journal of Business Ethics 125: 59-73.

Chen, S., Chen, X., Cheng, Q., dan Shevlin, T. 2010. Are Family Firms More Tax Aggressive Than Non-family Firms? Journal of Financial Economics 95: 4161.

Christensen, J., dan Murphy, R. 2004. The Social Irresponsibility of Corporate Tax Avoidanse: Taking CSR to the Bottom Line. Development 47(3): 37-44.

Davis, A. K., Guenther, D. A., Krull, L. K., dan Williams, B. M. 2016. Do Socially Responsible Firms Pay More Taxes? The Accounting Review 91: 47-68.

Deegan, C., Rankin, M., dan Tobin, J. 2002. An Examination of the Corporate Social and Environmental Disclosures pf BHP from 1983-1997: a Test of Legitimacy
Theory. Accounting, Auditing, and Accountibility Journal 15(3): 312-343.

Fama, E. F., dan Jensen, M. C. 1983. Separation Of Ownership And Control. Journal of Law and Economics 26: 301325.

Frank, M. M., Lynch, L. J., dan Rego, S. O. 2009. Tax reporting aggressiveness and its relation to aggressive financial reporting. The Accounting Review 84(2): 467-496.

Ghozali, I., dan Chariri, A. 2007. Teori Akuntansi. Semarang: Badan Penerbit Universitas Diponegoro.

Gray, R., Kouhy, R., dan Lavers, S., 1995. Corporate Social and Environmental Reporting: A Review of The Literature and a Longitudinal Study of UK Disclosure. Accounting, Auditing and Accountability Journal 8 (2), 47-77.

Gustian, V., dan Faisal. 2015. Analisis Perbandingan Penggunaan GRI Indeks dan ISR Indeks dalam Pengungkapan Tanggung Jawab Sosial Perusahaan Perbankan Indonesia Tahun 2010-2013. Diponegoro Journal of Accounting 4(4): 1-10

Hadi, N., 2011. Corporate Social Responsibility. Yogyakarta: Graha Ilmu.

Hadi, J., dan Mangoting, Y. 2014. Pengaruh Struktur Kepemilikan dan Karakteristik Dewan terhadap Agresivitas Pajak. Tax \& Accounting Review 4(2): 1-10.

Hanlon, M., dan Slemrod, J. 2009. What Does Tax Aggressiveness Signal? Evidence from Stock Price Reactions to News About Tax Shelter Involvement. Journal of Public Economics 93:126-141

Hanlon, M., dan Heitzman, S. 2010. A Review of Tax Research. Journal of Accounting and Economics 50(2-3): 127-178.

Harmono. 2014. Manajemen Keuangan. Edisi Ketiga. Jakarta: Bumi Aksara.

Hooghiemstra, R. 2000. Corporate Communication and Impression Management - New Perspectives Why Companies Engange in Corporate Social Reporting. Journal of Business Ethics 27: 55-68. 
Hu, Y., dan Izumida, S. 2008. The Relationship Between Ownership and Performance: A Review of Theory and Evidence. International Business Research 1(4): 72-81.

Ibrahim, N., Howard, D., dan Angelidis, J. 2003. Board Members in The Service Industry: An Empirical Examination of the Relationship Between Corporate social responsibility Orientation and Director Type. Journal of Business Ethics 47: 393-401.

Jensen, M. C. dan Meckling, W. H. 1976. Theory of The Firm: Managerial Behavior, Agency Cost and Ownership Structure. Journal of Financial Economics 3: 305-360.

Khaoula, A. dan Ali Z.M. 2012. The Board of Directors and the Corporate Tax Planning: Empirical Evidence from Tunisia. International Journal of Accounting and Financial Reporting. 2(2): 142-157.

KNKG. 2006. Pedoman Umum Good Governance Indonesia. Diakses 14 Maret 2018 dari http://www.knkgindonesia.org/dokumen/Pedoman-GoodPublic-Governance.pdf.

Kurniasih, T., dan Sari, M.M.R. 2013. Pengaruh Return On Assets, Leverage, Corporate Governance, Ukuran Perusahaan dan Kompensasi Rugi Fiskal pada Tax Avoidance. Buletin Studi Ekonomi 18(1): 58-66.

Laguir, I., Stagliano, R., dan Elbaz. 2015. J. Does Corporate social responsibility Affect Corporate Tax Aggressiveness?. Journal of Cleaner Production 107: 662675.

Laporan Tahunan Direktorat Jenderal Pajak. 2015. Diakses 13 Januari 2018, dari http://www.pajak.go.id/sites/default/files /DJP\%20AR\%202015\%20Fullpages\%2 0 \%20Indonesia\%20\%28Lowres\%29.pdf.

Lanis, R., dan Richardson, G. 2011. The Effect of Board of Director Composition on Corporate Tax Aggressiveness.
Journal of Accounting and Public Policy 30: 50-70.

Lanis, R., dan Richardson, G. 2012. Corporate social responsibility and Tax Aggresiveness: an Empirical Analysis. Journal of Accounting and Public Policy 31: 86-108.

Mayangsari, L. P., dan Andayani. 2015. Pengaruh Good Corporate Governance dan Kinerja Keuangan terhadap Financial Distress. Jurnal Ilmu dan Riset Akuntansi. 4(4): 1-18.

Musyarrovah, E., dan Amanah, L. 2017. Pengaruh Kepemilikan Manajerial, Leverage dan Size terhadap Cash Effective Tax Rate. Jurnal Ilmu dan Riset Akuntansi 6(9): 1-16.

Nota Keuangan Beserta Rancangan Anggaran Pendapatan dan Belanja Negara. 2017. Diakses $21 \quad$ Februari 2018. http://www.anggaran.depkeu.go.id/conte nt/Publikasi/NK\%20APBN/2016\%20N K\%20RAPBN\%202017.pdf.

Novitasari, S., Ratnawati, V., dan Silfi A. 2017. Pengaruh Manajemen Laba, Corporate Governance, dan Intensitas Modal terhadap Agresivitas Pajak Perusahaan. Jurnal Online Mahasiswa 4(1): 1901-1914.

O'donovan, G. 2002. Environmental Disclosure in the Annual Report: Extending the Applicability an Predictive Power of Legitimacy Theory. Accounting, Auditing \& Accountibility Journal 15(3) 344-371.

Peraturan Otoritas Jasa Keuangan No, 33/POJK.04/2014 tentang Direksi dan Dewan Komisaris Emiten atau Perusahaan Publik.

Puspita, D., dan Febrianti, M. 2017. FaktorFaktor yang Mempengaruhi Penghindaran Pajak pada Perusahaan Manufaktur di Bursa Efek Indonesia. Jurnal Bisnis dan Akuntansi 19(1): 3846.

Rose, J.M. 2007. Corporate Directors and Social Responsibility: Ethics Versus Shareholder Value. Journal of Business Ethics 73: 319-331. 
Rusdianto, U. 2013. CSR Communications: A Framework for PR Practitioners. Yogyakarta: Graha Ilmu.

Rosalia, Y,. dan Sapari. 2017. Pengaruh Profitabilitas, Likuiditas dan Corporate Gocernance terhadap Penghindaran Pajak. Jurnal Ilmu dan Riset Akuntansi 6(3): 890-909.

Santoso, Iman dan Ning Rahayu. 2013. Corporate Tax Management. Jakarta: Observation \& Research of Taxation (Ortax).

Sari, D. K., dan Martani, D. 2010. Ownership Characteristics, Corporate Governance, and Tax Aggressiveness. Paper presented at The 3rd Accounting \& The 2nd Doctoral Colloquium Bridging the Gap between Theory, Research and Practice: IFRS Convergence and Application Faculty of Economics Universitas Indonesia.

Siregar, R., dan Widyawati, D. 2016. Pengaruh Karakteristik Perusahaan terhadap Penghindaran Pajak pada Perusahaan Manufaktur di BEI. Jurnal Ilmu dan Riset Akuntansi 5(2): 1-17.

Suchman, M. 1995. Managing Legitimacy: Strategic and Institutional Approaches. Academy of Management Review 20 (3): 571-611.

Suedi, B., dan Warno. 2010. Pengaruh Sistem Informasi terhadap Kejujuran Laporan Keuangan Manajer: Sebuah Persepektif Perilaku. Jurnal STIE Semarang 2(1): 114.

Sudana, I. M. 2011. Manajemen Keuangan Perusahaan: Teori dan Praktik. Edisi kedua. Jakarta: Erlangga.

Suprapti, E. 2016. Pengaruh Tekanan Keuangan terhadap Penghindaran Pajak. Jurnal Reviu Akuntansi dan Keuangan 7(2): 1013-1022.

Suyanto, K. D., dan Supramono. 2012. Likuiditas, Leverage, Komisaris Independen dan Manajemen Laba Terhadap Agresivitas Pajak Perusahaan. Jurnal Keuangan dan Perbankan 16(2): 167-177.

Tan, A., Benni, D., dan Liani, W. 2016. Determinants of Corporate social responsibility Disclosure and Investor Reaction. International Journal of Economics and Financial Issues 6(S4): 11-17.

The World Business Council for Sustainable Development (WBSD). 2002. Corporate social responsibility Responsibility. Diakses 18 Maret 2018, dari https://www.globalhand.org/system/asse ts/f65fb8b06bddcf2f2e5fef11ea7171049 f223d85/original/Corporate_Social_Res ponsability_WBCSD_2002.pdf.

Undang-Undang Republik Indonesia Nomor 40 Tahun 2007 Tentang Perseroan Terbatas.

Wahyudi, I., dan Azheri, B. 2011. Corporate Social Responsibility: Prinsip, Pengaturan dan Implementasi. Jakarta: Setara Press.

Wilson, R.J. 2009. An Examination of Corporate Tax Shelter Participants. The Accounting Review 84(3): 969-999.

World Bank. Diakses 13 Januari 2018, dari https://data.worldbank.org/indicator/GC. TAX.TOTL.GD.ZS.

Zemzem, A., dan Ftouhi. K. 2013. The Effect of Board of Director's Characteristic on Tax Aggressiveness. Research Journal of Finance and Accounting 4(4): 140-147. 